\title{
FEMALE MOUSE MATURATION: RELATIVE IMPORTANCE OF SOCIAL FACTORS AND DAYLENGTH
}

\author{
L. C. DRICKAMER \\ Biology Department, Williams College, \\ Williamstown, Massachusetts 01267, U.S.A.
}

(Received 30th December 1974)

\begin{abstract}
Summary. The present experiment utilized a cross-classified design to test the interactions and relative importance of male presence or absence, female density and three different photoperiods as factors affecting puberty in female house mice. First vaginal oestrus was used as the criterion for sexual maturity. All three factors significantly affected the timing of first oestrus; male presence or absence accounted for $31 \%$ of the total variation in age at maturity, $9 \%$ of the variance was attributable to the female density factor and $6 \%$ to differences in daylength treatments. There were no significant interactions among the treatment variables. These results conform with a general model relating the processes of sexual and morphological development.
\end{abstract}

To understand the complex of factors which affect the timing of sexual maturation in rodents, studies are needed to examine the interactions of various parameters, each of which has previously been investigated separately. Vandenbergh, Drickamer \& Colby (1972) showed, with a cross-classified design, that dietary protein and the male-induced acceleration of first oestrus, significantly affected the time of onset of puberty in house mice and that the latter factor was twelve times more important than the former. The purpose of the present experiment was to test the interactions and relative importance of three variables that are known to influence the sexual maturation of female mice: (1) acceleration in the presence of an adult male mouse (Vandenbergh, 1967, 1969; Kennedy \& Brown, 1970; Fullerton \& Cowley, 1971; Colby \& Vandenbergh, 1974); (2) delay produced by grouping young female mice (Gastro, 1967; Champlin, 1971; Cowley \& Wise, 1972; Drickamer, 1974) and (3) daylength (Drickamer, 1975).

A cross-classified experimental design was used. This involved the presence or absence of an adult intact male, female densities of one, four or seven mice per cage and photoperiods of 0,12 or $24 \mathrm{hr}$ light $/ 24 \mathrm{hr}$ (see Table 1). A total of 432 mice was used, providing a sample size of twelve mice per cell. The mice were taken from a random-bred closed-colony stock of ICR/Alb Mus musculus. All colony and experimental mice were housed in shoe-box cages of polypropylene, measuring $15 \times 28 \times 15 \mathrm{~cm}$ and with opaque sides and fitted wire lids. The mouse colony and experimental rooms were maintained at 21 to $25^{\circ} \mathrm{C}$ and 30 to $60 \%$ relative humidity. Three test rooms were utilized, each 
containing fluorescent lighting (intensity of 30 lux at $1 \mathrm{~m}$ above the floor) and a timer box, permitting control of the photoperiod at 0,12 or $24 \mathrm{hr}$ light $/ 24 \mathrm{hr}$. The colony room, where the mice were born and reared before being used experimentally, was maintained on a 12-hr light/12-hr dark daily cycle. The litter of wood shavings in each cage was changed once weekly; Wayne Labblox and water were freely supplied throughout the investigation.

Pregnant female mice were isolated in individual cages during the last week of gestation. All cages were then checked daily for births. On the day after birth the young in each litter were counted and sexed. Each litter was reduced to ten young, at least one of which was a male, and litters of $<10$ young were discarded. The young mice were weaned 21 days after birth and were immediately assigned to a treatment group and cage according to a random sequence. Within each cage, one mouse was selected at random as the test mouse and was marked by clipping one toe. Singly-caged mice were also toe-clipped.

Each mouse was examined daily from Day 21 until the occurrence of vaginal perforation. Starting on the day of vaginal perforation, a daily vaginal lavage was taken each day until the occurrence of first vaginal oestrus. The wetmount vaginal smears were examined immediately with a microscope and the cellular contents were evaluated to determine the stage of the oestrous cycle according to the criteria of Vandenbergh (1969) and Vandenbergh et al. (1972). Each mouse was weighed to the nearest $0.1 \mathrm{~g}$ on the day of vaginal perforation, on the day of first oestrus and on Days 21, 28, 35 and 42 of age.

Table 1. Mean age in days ( \pm 1 S.E.) at first vaginal oestrus in young female house mice maintained under three different treatments

\begin{tabular}{|c|c|c|c|c|c|c|c|}
\hline \multirow[b]{2}{*}{ Females/cage: } & \multicolumn{3}{|c|}{ Male present } & \multicolumn{3}{|c|}{ Male absent } & \multirow[b]{2}{*}{$\mathrm{X}$} \\
\hline & 1 & 4 & 7 & 1 & 4 & 7 & \\
\hline $\begin{array}{c}\text { Light } / 24 \mathrm{hr} \\
0 \mathrm{hr} \\
12 \mathrm{hr} \\
24 \mathrm{hr}\end{array}$ & $\begin{array}{l}28 \cdot 1 \pm 0.7 \\
26 \cdot 8 \pm 0.5 \\
29.2 \pm 0.8\end{array}$ & $\begin{array}{l}30 \cdot 7 \pm 1 \cdot 1 \\
31 \cdot 6 \pm 1 \cdot 1 \\
32 \cdot 8 \pm 1 \cdot 2\end{array}$ & $\begin{array}{l}32 \cdot 2 \pm 1 \cdot 6 \\
33 \cdot 2 \pm 1 \cdot 3 \\
33 \cdot 9 \pm 1 \cdot 1\end{array}$ & $\begin{array}{l}34 \cdot 3 \pm 1 \cdot 5 \\
33 \cdot 8 \pm 1 \cdot 1 \\
40 \cdot 2 \pm 1 \cdot 6\end{array}$ & $\begin{array}{l}36 \cdot 4 \pm 2 \cdot 0 \\
35 \cdot 4 \pm 1 \cdot 6 \\
43 \cdot 2 \pm 1 \cdot 1\end{array}$ & $\begin{array}{l}37 \cdot 4 \pm 1 \cdot 2 \\
37 \cdot 3 \pm 2 \cdot 3 \\
44 \cdot 8 \pm 1 \cdot 1\end{array}$ & $\begin{array}{l}33 \cdot 2 \\
33 \cdot 0 \\
37 \cdot 4\end{array}$ \\
\hline $\mathbf{X}$ & $28 \cdot 0$ & $31 \cdot 7$ & $33 \cdot 1$ & $36 \cdot 1$ & 38.4 & $39 \cdot 5$ & \\
\hline
\end{tabular}

$\begin{array}{ll}\mathbf{F}_{1,198} \text { (Male presence/absence) } & =128 \cdot 72, P<0 \cdot 01 . \\ \mathbf{F}_{2,198} \text { (Daylength) } & =18 \cdot 60, P<0 \cdot 01 . \\ \mathbf{F}_{2,198} \text { (Female density) } & =13 \cdot 12, P<0.01 .\end{array}$

The results for first vaginal oestrus and the significant F-ratios from an analysis of variance (Table 1) indicate that all three treatment factors were significant. Mice caged with an adult male mouse attained puberty significantly earlier than females housed alone, females housed in groups of four or seven per cage reached first oestrus later than females caged alone, and females housed under constant illumination matured significantly later than females kept in photoperiods of 0 or $12 \mathrm{hr}$ light/day. There were no significant interactions among the three treatment factors. Analysis of the data for age at vaginal 
perforation revealed similar patterns of significant differences for the three main treatment factors and no significant interactions among the three variables tested.

There were no significant body weight differences at first oestrus for mice housed in the three photoperiods and no significant interactions among the three factors tested (Table 2). The male presence or absence and the female density treatments, however, revealed significant differences in mean body weight at first oestrus. Mice caged with males had lighter body weights at puberty than females housed alone, and young females reared individually attained first oestrus at lighter mean body weights than females caged in groups.

Table 2. Mean body weight in $g( \pm 1$ S.E.) at first oestrus in young female house mice maintained under three different treatments

\begin{tabular}{|c|c|c|c|c|c|c|c|}
\hline \multirow[b]{2}{*}{ Females/cage: } & \multicolumn{3}{|c|}{ Male present } & \multicolumn{3}{|c|}{ Male absent } & \multirow[b]{2}{*}{$\overline{\mathrm{x}}$} \\
\hline & 1 & 4 & 7 & 1 & 4 & 7 & \\
\hline $\begin{array}{c}\text { Light } / 24 \mathrm{hr} \\
0 \mathrm{hr} \\
12 \mathrm{hr} \\
24 \mathrm{hr}\end{array}$ & $\begin{array}{l}20.1 \pm 0.6 \\
18.9 \pm 0.6 \\
20.7 \pm 0.6\end{array}$ & $\begin{array}{l}20 \cdot 9 \pm 0.8 \\
22 \cdot 0 \pm 0.9 \\
22 \cdot 7 \pm 0 \cdot 7\end{array}$ & $\begin{array}{l}22 \cdot 2 \pm 0 \cdot 5 \\
23 \cdot 2 \pm 0 \cdot 8 \\
22 \cdot 5 \pm 1 \cdot 0\end{array}$ & $\begin{array}{l}23.8 \pm 0.7 \\
22.9 \pm 0.7 \\
22.9 \pm 0.6\end{array}$ & $\begin{array}{l}23 \cdot 7 \pm 0.6 \\
24 \cdot 0 \pm 0.7 \\
23 \cdot 4 \pm 0.9\end{array}$ & $\begin{array}{l}23.7 \pm 1 \cdot 0 \\
23.7 \pm 0.8 \\
23.5 \pm 0.6\end{array}$ & $\begin{array}{l}22 \cdot 4 \\
22 \cdot 4 \\
22 \cdot 5\end{array}$ \\
\hline $\mathbf{X}$ & $19 \cdot 9$ & $21 \cdot 9$ & $22 \cdot 6$ & $23 \cdot 2$ & $23 \cdot 7$ & $23 \cdot 8$ & \\
\hline
\end{tabular}

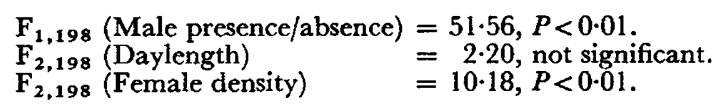

Several conclusions emerge from these data: (1) all three test factors had a significant influence on the timing of sexual maturation; (2) male presence or absence accounted for $31 \%$ of the total variance in age at sexual maturity, whereas the female density accounted for $9 \%$ of the total variance and daylength $6 \%$; and (3) mice caged in different photoperiods matured at the same mean body weight, but there were significant body weight differences at sexual maturity for both the male presence or absence and female density factors.

The results of this investigation conform to the general model expressed by Drickamer (1975) for factors affecting sexual maturation in female mice and the relationship between sexual and physical development. The model asserts that there are two programmes, one controlling the physical development of the animal and one controlling the sexual development. In control mice reared alone on a standard diet and in a 12-hr light/12-hr dark photoperiod, there is a strong correlation between morphological and sexual development. A variety of factors can influence either or both of these developmental programmes, which may proceed at different rates. The significant findings of the present study were that the three treatment variables, presence or absence of a male, female density and daylength, each appear to act separately in altering the physical and sexual development of the house mouse, and that each factor alone accounts for a significant percentage of the total variation in age at puberty. 
The author was supported in part by a National Institutes of Mental Health Grant No. 24483 from the United State Public Health Service and by Sloan Foundation Discretionary Funds from Williams College.

\section{REFERENGES}

Castro, B. M. (1967) Age of puberty in female mice: Relationship to population density and the presence of adult males. An. Acad. Bras. Ciencia, 39, 289-292.

Champlin, A.K. (1971) Suppression of oestrus in grouped mice: the effects of various densities and the possible nature of the stimulus. F. Reprod. Fert. 27, 233-241.

Golby, D. F. \& VAndenbergh, J. G. (1974) Regulatory effects of urinary pheromones on puberty in the mouse. Biol. Reprod. 11, 268-279.

Cowley, J. J. \& WISE, D. R. (1972) Some effects of mouse urine on neonatal growth and reproduction. Anim. Behav. 20, 499-506.

Drickamer, L. G. (1974) Sexual maturation of female house mice: social inhibition. Devl Psychobiol. 7, 257-265.

Drickamer, L. G. (1975) Daylength and sexual maturation in female house mice. Devl Psychobiol. (in press).

Fullerton, G. \& Gowley, J. J. (1971) The differential effect of the presence of adult male and female mice on the growth and development of the young. 7. Genet. Psychol. 119, 89-98.

Kennedy, J. M. \& Brown, K. (1970) Effects of male odor during infancy on the maturation, behavior and reproduction of female mice. Devl Psychobiol. 3, 179-189.

VANDENBERGH, J. G. (1967) Effect of the presence of a male on the sexual maturation of female mice. Endocrinology, 81, 345-349.

VANDENBERGH, J. G. (1969) Male odor accelerates female sexual maturation in mice. Endocrinology, 84, $658-660$.

Vandenbergh, J. G., Drickamer, L. C. \& Golby, D. R. (1972) Social and dietary factors in the sexual maturation of female mice. F. Reprod. Fert. 28, 397-405. 